\title{
The cost of kidney dialysis in hospitals affiliated to Kurdistan University of Medical Sciences in 2016
}

\author{
Frdin Gharibi $^{{ }^{*}}$, Seifollah Moradi ${ }^{2}$, Salahadin Farshadi $^{3}$, Mozhdeh Zarei ${ }^{4}$, Masoud Rasolabadi ${ }^{5}$
}

\begin{tabular}{l} 
ARTICLE INFO \\
\hline Article History: \\
Received 8 January 2018 \\
Revised 10 January 2018 \\
Accepted 11 January 2018 \\
Published online 15 January 2018 \\
\hline
\end{tabular}

Keywords:

Cost analysis;

Cost-benefit analysis;

Cost-effectiveness;

Kurdistan

${ }^{1}$ M.Sc of Health Management, Kurdistan University of Medical Sciences, Sanandaj, Iran. ${ }^{2} \mathrm{PhD}$ of Business Management, Kurdistan University of Medical Sciences, Sanandaj, Iran ${ }^{3}$ M.Sc of Health Services management, Kurdistan University of Medical Sciences, Sanandaj, Iran ${ }^{4}$ M.Sc of Midwifery, Kurdistan University of Medical Sciences, Sanandaj, Iran ${ }^{5}$ M.Sc of Medical Library and Information Science, Kurdistan University of Medical Sciences, Sanandaj, Iran

\section{Correspondence}

Frdin Gharibi M.Sc of Health management, Kurdistan University of Medical Sciences, Sanandaj, Iran.

Email:Fardin.gharibi135@gmail.com

\begin{abstract}
Introduction: The first step for cost-benefit analysis and cost-effectiveness and ultimately to formulate the operational budgeting is cost analysis. The aim of this study was to evaluate the cost of kidney dialysis services in hospitals affiliated to Kurdistan University of Medical Sciences in 2016.

Methods: This cross sectional study was conducted on 9 dialysis clinics of hospitals affiliated to Kurdistan University of Medical Sciences in the first half of 2016. In each hospital all dialysis cases were selected by census method. The costs were included personnel costs, medication, medical supplies, filters, solvent and powder, consumables and energy carriers. Data collected from documents available in the hospital information system (Ghasedak). Data was computed and presented as the mean and absolute numbers using Microsoft Excel software.

Result: In terms of dialysis clinic gross income per the number of active hemodialysis beds Dehgolan dialysis center with 656205 thousand Rials had the highest income and Qorveh dialysis center with 296216 thousand Rials had the lowest. The average income per dialysis session Bijar dialysis center with 3033 thousand Rials had the highest income and Tohid hospital dialysis center with 1500 thousand Rials had the lowest. Average personnel payment per dialysis session in Kamyaran dialysis center with 621 thousand Rials had the lowest and Bijar dialysis center with 1317 thousand Rials had the highest payment. In terms of medicine and supplies Divandareh dialysis center had the highest and Boali hospital dialysis center had the lowest. Calculating cost-income per each dialysis session showed that Tohid hospital, Saghez, Divandareh and Dehgolan dialysis centers were losers.

Conclusion: The cost of dialysis services in the dialysis centers of hospitals affiliated to Kurdistan University of Medical Sciences were not the same as tariffs of insurance organizations. Therefore, the tariffs of dialysis services in the dialysis centers of hospitals affiliated to Kurdistan University of Medical Sciences should be managed or increased or the dialysis services provide by private sector.
\end{abstract}

\section{Introduction}

$\mathrm{P}$ roviding health services to people regardless of service cost in the context of designated plans and objectives has become challenging this question; is it possible to provide quality services with fewer resources? Awareness of health services cost is a prerequisite for health managers and planners (1). Considering that the main part of health services in our country is provided by the government sector, there is usually no logical relationship between received services and paid fees. On the other hand, the increasing need of people for more services leads to a lack of resources in this sector. This problem has prompted health managers and planners to think about ways to reduce the costs and make optimal use of existing resources. Therefore, cost analysis help health managers to find ways and manage costs (2). The first step for cost-benefit analysis and costeffectiveness and ultimately to formulate the operational budgeting is cost analysis. Determining 
the price is useful for health managers, because it makes them understand whether the funds spent to achieve the objectives of the organization or not? Performance is acceptable when the expected result is achieved with a minimum cost (3). At the hospital level which $70 \%$ of the health sector credits are accounted for, lack of information resources, reliance on state budget, lack of transparency and lack of clarity about the actual cost of provided services has led to the inefficiency of spent resources, and sometimes wasting them (4). There are various methods for costing. One of these methods is activity-based costing which by using appropriate method and considering the effects of changes in activities, complexity, diversity and specificity of each activity calculate the cost (5). The lack of real tariffs in the health sector has a harmful effect on the health system. In many cases, the cost of health services calculated lower than their real cost (6). Given the particular conditions of the dialysis section the cost of its services in the public sector is important. Determining the cost of dialysis services based on activity-based costing can be used as the basis for determining tariffs, because the price calculated in this way is very consistent with the actual costs. Therefore, the aim of this study was to evaluate the cost of kidney dialysis services in hospitals affiliated to Kurdistan University of Medical Sciences in 2016.

\section{Methods}

This cross sectional study was conducted on 9 dialysis clinics of hospitals affiliated to Kurdistan University of Medical Sciences in the first half of and powder, consumables and energy carriers. Personnel costs included (salary, tuition, overtime, by census method. The costs were included personnel
2016. In each hospital all dialysis cases were selected costs, medication, medical supplies, filters, solvent clothing cost, housing cost) was calculated based on financial records and hospital information system (HIS). The cost of medication, medical supplies, filters, solvent and powder was calculated based on the order of the warehouse to the dialysis center. The cost of energy carriers (Gas, electricity, water,) were determined based on the costs paid for hospital energy carriers. Data collected from documents available in the hospital information system. Data was computed and presented as the mean and absolute numbers using Microsoft Excel software. In the next step, a sharing basis was defined for the cost sharing of each activity center. For example, salary and benefit costs divided based on the number of personnel and the cost of consumed stuff divided based on the number of dialysis sessions and energy costs divided based on square meters. At the end, the share and amount of each cost for each dialysis session were determined and finally the cost of each dialysis session was determined and compared by city. Collected data was analyzed using excel software and presented in terms of mean, standard deviation and absolute number.

\section{Results}

The results showed that in 9 dialysis centers of Kurdistan University of Medical Sciences dialysis centers of Tohid Hospital with 4949690 thousand Rials had the highest personnel payment and dialysis centers of Bijar Hospital with 1010107 thousand Rials had the lowest personnel payment. (Table 1) The staff of dialysis center of Divandareh during 6 months of summer and fall with average of 840 hours had the lowest working hours while the staff of dialysis center of Ghoveh with 1522 hours had the

Table 1: Payments to staff of dialysis centers in hospitals affiliated to Kurdistan University of Medical Sciences the first half of 2016 (in Rials)

\begin{tabular}{|c|c|c|c|c|c|c|c|}
\hline Hospital & Salary & Housing & Cloths & Extra & Mandatory payment & Non-Mandatory payment & Total \\
\hline Tohid & $3,135,068$ & 94,400 & 10,891 & 83,338 & 776,525 & 849,468 & $4,949,690$ \\
\hline Saghez & $3,138,268$ & 75,200 & 8,676 & 66,388 & 852,833 & 448,645 & $4,590,010$ \\
\hline Boali & $1,795,063$ & 42,400 & 4,892 & 37,431 & 420,722 & 495,041 & $2,795,548$ \\
\hline Bane & $1,216,265$ & 30,400 & 3,507 & 26,838 & 317,226 & 372,419 & $1,966,655$ \\
\hline Divandareh & 907,843 & 33,600 & 3,877 & 29,663 & 252,166 & 81,230 & $1,308,378$ \\
\hline Kamyaran & 730,651 & 30,400 & 3,507 & 26,838 & 336,190 & 176,394 & $1,303,980$ \\
\hline Dehgolan & 723,649 & 27,200 & 3,138 & 24,013 & 332,121 & 121,174 & $1,231,295$ \\
\hline Ghrove & 683,884 & 19,200 & 2,215 & 16,950 & 194,854 & 201,656 & $1,118,760$ \\
\hline Bijar & 594,989 & 21,600 & 19,069 & 2,492 & 293,994 & 77,964 & $1,010,107$ \\
\hline Total & $12,925,679$ & 374,400 & 59,773 & 313,948 & $3,776,632$ & $2,823,991$ & $20,274,423$ \\
\hline
\end{tabular}


Table 2: The working status of the staff of the dialysis centers to Kurdistan University of Medical Sciences in the first half of 2016

\begin{tabular}{|l|l|l|l|l|l|l|l|l|}
\hline Hospital & $\begin{array}{l}\text { No. of } \\
\text { Staff }\end{array}$ & $\begin{array}{l}\text { Obligatory } \\
\text { working } \\
\text { Hours }\end{array}$ & $\begin{array}{l}\text { On } \\
\text { call }\end{array}$ & $\begin{array}{l}\text { Non } \\
\text { Obligatory } \\
\text { working } \\
\text { Hours }\end{array}$ & $\begin{array}{l}\text { Total } \\
\text { working } \\
\text { hours }\end{array}$ & $\begin{array}{l}\text { Working } \\
\text { hours/Dialysis } \\
\text { Session }\end{array}$ & $\begin{array}{l}\text { Average of staff } \\
\text { working hours }\end{array}$ & $\begin{array}{l}\text { Average of } \\
\text { Dialysis } \\
\text { Session /staff }\end{array}$ \\
\hline Tohid & 20 & 16,783 & 2,852 & 8,212 & 24,995 & 2.4 & 1,250 & 511 \\
\hline Saghez & 15 & 14,467 & 2,200 & 3,421 & 17,888 & 3 & 1,193 & 403 \\
\hline Boali & 9 & 7,719 & - & 3,798 & 11,517 & 3 & 1,280 & 424 \\
\hline Bane & 6 & 4,530 & - & 2,679 & 7,209 & 2.2 & 1,202 & 550 \\
\hline Divandareh & 7 & 5,087 & 96 & 794 & 5,881 & 4.2 & 840 & 199 \\
\hline Kamyaran & 5 & 5,018 & 2,454 & 1,333 & 6,351 & 2.4 & 1,270 & 537 \\
\hline Dehgolan & 5 & 5,149 & - & 917 & 6,066 & 4.9 & 1,213 & 247 \\
\hline Ghrove & 3 & 2,942 & 185 & 1,625 & 4,567 & 2.3 & 1,522 & 672 \\
\hline Bijar & 4 & 4,496 & 5,843 & 902 & 5,398 & 5.5 & 1,350 & 247 \\
\hline Total & 75 & 66,191 & 13,630 & 23,681 & 89,872 & 2.8 & 1,214 & 428 \\
\hline
\end{tabular}

Table 3: The income of dialysis centers of Kurdistan University of Medical Sciences in the first half of 2016 (in Rials)

\begin{tabular}{|c|c|c|c|c|c|}
\hline Hospital & $\begin{array}{l}\text { Gross income ratio of } \\
\text { dialysis centers To } \\
\text { Hospital }\end{array}$ & $\begin{array}{l}\text { Proportion of deductions } \\
\text { of dialysis centers To } \\
\text { Hospital }\end{array}$ & $\begin{array}{l}\text { Base income ratio } \\
\text { to Gross income } \\
\text { ratio }\end{array}$ & $\begin{array}{l}\text { Income to active } \\
\text { bed (Thousand } \\
\text { Rials) }\end{array}$ & $\begin{array}{l}\text { Income to dialysis } \\
\text { session (Thousand } \\
\text { Rials) }\end{array}$ \\
\hline Tohid & $3.10 \%$ & $9.60 \%$ & $33.40 \%$ & 528,462 & 1,500 \\
\hline Saghez & $4.40 \%$ & $7.30 \%$ & $33.40 \%$ & 488,861 & 1,536 \\
\hline Boali & $4.20 \%$ & $3.10 \%$ & $52.60 \%$ & 395,846 & 1,869 \\
\hline Bane & $3.40 \%$ & $10.90 \%$ & $44.50 \%$ & 614,148 & 1,863 \\
\hline Divandareh & $3.70 \%$ & $2.70 \%$ & $48.60 \%$ & 419,235 & 2,107 \\
\hline Kamyaran & $6.20 \%$ & $18.70 \%$ & $29.40 \%$ & 478,658 & 1,962 \\
\hline Dehgolan & $7.00 \%$ & $0.30 \%$ & $52.80 \%$ & 656,205 & 2,125 \\
\hline Ghrove & $2.70 \%$ & $4.10 \%$ & $50.90 \%$ & 296,216 & 1,910 \\
\hline Bijar & $2.90 \%$ & $5.20 \%$ & $64.80 \%$ & 428,470 & 3,033 \\
\hline Total & $3.70 \%$ & $8.00 \%$ & $41.30 \%$ & 470,807 & 1,753 \\
\hline
\end{tabular}

highest working hours. In terms of average working hours per dialysis session the staff of dialysis center of Dehgolan with 4.9 hours and Ghorveh with 2.3 hours had the highest and lowest average working hours per dialysis session respectively. The average number of dialysis sessions per staff in Ghorveh with 627 sessions was the highest and in Divandareh with 199 sessions was the lowest (Table 2). In terms of dialysis clinic gross income per the number of active hemodialysis beds Dehgolan dialysis center with 656205 thousand Rials had the highest income and Qorveh dialysis center with 296216 thousand Rials had the lowest. The average income per dialysissession Bijar dialysis center with 3033 thousand Rials had the highest income and Tohid hospital dialysis center with 1500 thousand Rials had the lowest (Table 3). Average personnel payment per dialysis session in Kamyaran dialysis center with 621 thousand Rials had the lowest and Bijar dialysis center with 1317022 thousand Rials had the highest payment. In terms of medicine and supplies Divandareh dialysis center had the highest and Boali hospital dialysis center had the lowest. (Table 4). The share of the cost of each dialysis session is presented in table 5. Calculating cost-income per each dialysis session showed that Tohid hospital, Saghez centers were losers. The results showed that income $\mathrm{z}$, Divandareh and Dehgolan dialysis centers were losers. The results showed that income level of each dialysis session for all 9 dialysis centers of hospitals affiliated to Kurdistan University of Medical Sciences with 25435 Rials was positive (Table 6).

\section{Discussion}

According to the findings of this study, there are significant differences in the number of staff to the 
Table 4: Average cost of each dialysis session in hospitals of Kurdistan University of Medical Sciences in the first half of 2016 (in Rials)

\begin{tabular}{|c|c|c|c|c|c|c|c|}
\hline Hospital & $\begin{array}{l}\text { Medicine and } \\
\text { supplies }\end{array}$ & Filter & $\begin{array}{l}\text { Non consumable } \\
\text { supplies }\end{array}$ & $\begin{array}{l}\text { Payment to } \\
\text { Staff }\end{array}$ & $\begin{array}{l}\text { Energy Carriers } \\
\text { and Tell }\end{array}$ & $\begin{array}{l}\text { Payment to } \\
\text { Physicians }\end{array}$ & Total \\
\hline Tohid & 399,158 & 455,783 & 3,670 & 484,361 & 22,806 & 252,530 & $1,618,308$ \\
\hline Saghez & 399,478 & 511,036 & 4,797 & 759,181 & 23,886 & 127,680 & $1,826,058$ \\
\hline Boali & 334,633 & 493,867 & 4,119 & 733,355 & 24,940 & 91,431 & $1,682,345$ \\
\hline Bane & 338,989 & 491,572 & 4,064 & 596,498 & 38,604 & 108,912 & $1,578,639$ \\
\hline Divandareh & 424,767 & 602,118 & 5,097 & 939,252 & 39,177 & 130,190 & $2,140,601$ \\
\hline Kamyaran & 494,545 & 524,056 & 6,150 & 486,016 & 37,560 & 135,213 & $1,683,540$ \\
\hline Dehgolan & 539,785 & 456,923 & 6,640 & 997,000 & 20,503 & 140,228 & $2,161,079$ \\
\hline Ghrove & 349,696 & 509,000 & 4,663 & 554,940 & 42,374 & 157,218 & $1,617,891$ \\
\hline Bijar & 386,322 & 522,523 & 7,887 & $1,021,342$ & 60,168 & 295,680 & $2,293,922$ \\
\hline Total & 396,332 & 492,355 & 4,756 & 639,774 & 29,202 & 169,987 & $1,732,406$ \\
\hline
\end{tabular}

Table 5: The cost of each dialysis session in hospitals of Kurdistan University of Medical Sciences in the first half of 2016 (in Rials)

\begin{tabular}{l|l|l|l|l|l|l|l|l|l|l|}
\hline \multirow{2}{*}{ Hospital } & \multicolumn{3}{c}{ Staff } & Medicine and supplies & \multicolumn{2}{|c|}{ Energy Carriers and Tell } & \multicolumn{2}{c}{ Total } \\
& $\%$ & Cost & $\%$ & Cost & $\%$ & Cost & $\%$ & Cost \\
\hline Tohid & 45.6 & 736,891 & 52.9 & 854,941 & 1.4 & 22,806 & 100 & $1,614,638$ \\
\hline Saghez & 48.7 & 886,861 & 50 & 910,514 & 1.3 & 23,886 & 100 & $1,821,261$ \\
\hline Boali & 49.1 & 824,786 & 49.4 & 828,500 & 1.5 & 24,940 & 100 & $1,678,226$ \\
\hline Bane & 44.8 & 705,410 & 52.7 & 830,561 & 2.5 & 38,604 & 100 & $1,574,575$ \\
\hline Divandareh & 50.1 & $1,069,442$ & 48.1 & $1,026,885$ & 1.8 & 39,177 & 100 & $2,135,504$ \\
\hline Kamyaran & 37 & 621,229 & 60.7 & $1,018,601$ & 2.2 & 37,560 & 100 & $1,677,390$ \\
\hline Dehgolan & 52.8 & $1,137,228$ & 46.3 & 996,708 & 1 & 20,503 & 100 & $2,154,439$ \\
\hline Ghrove & 44.1 & 712,158 & 53.2 & 858,696 & 2.6 & 42,374 & 100 & $1,613,228$ \\
\hline Bijar & 57.6 & $1,317,022$ & 39.8 & 908,845 & 2.6 & 60,168 & 100 & $2,286,035$ \\
\hline Total & 46.9 & 809,761 & 51.4 & 888,687 & 1.7 & 29,202 & 100 & $1,727,650$ \\
\hline
\end{tabular}

dialysis bed, personnel working hours (up to twice), the average of working hours per dialysis session (2.2 times) and the number of hemodialysis per staff (3.15 times) which indicate that the distribution of manpower and work schedules (staff shift) in the hemodialysis centers of hospitals affiliated to Kurdistan University of Medical Sciences is not coordinated and mostly is based on personal judgment. The gross income of dialysis center to the number of active hemodialysis beds showed the 2.2 difference of Dehgolan compared to Qorveh which indicates that the hemodialysis beds are distribyted inappropriately and that the number of hemodialysis beds in some cities are more than needed. The average gross income to the dialysis session also indicates a twofold difference in the Bijar dialysis center to Tohid Hospital dialysis center. Although, due to the same global payment, the hemodialysis cost of the hospitals by the insurance organizations, the existence of a twofold difference in the cost of each dialysis session is highly debatable and poses a lot of ambiguity. Is the income data calculated from HIS which is the basis for payment to staff andphysicians not correct? The difference between the average payment to staff and doctors for each dialysis session in different cities confirms this issue. In a study by Ganbari et al, they calculated difference of $30 \%$ between tariff and dialysis cost Imam Sajjad Hospital in Shahriar (7). Rezapur also estimated the variance of financial disadvantage for each referral period to receive a hemodialysis service of 15,916 Rials (8). Although, with the implementation of the health promotion plan, many of the tariffs for services increased significantly, but the hemodialysis tariff did not increase significantly. Calculating costincome per each dialysis session showed that Tohid hospital, Saghez, Divandareh and Dehgolan dialysis centers were losers. In general, the income of each session of dialysis centers of hospitals affiliated to Kurdistan University of Medical Sciences was 25435 Rials. It is necessary to explain that in the calculated costs, the overhead costs such as support units, 
Table 6: Average cost and revenue per dialysis session in hospitals of Kurdistan University of Medical Sciences in the first half of 2016 (in Rials)

\begin{tabular}{l|c|c|c|}
\hline Hospital & The Cost of each session & The income of each session & Difference \\
\hline Tohid & $1,614,638$ & $1,499,697$ & $\mathbf{- 1 1 4 , 9 4 1}$ \\
\hline Saghez & $1,821,261$ & $1,536,282$ & $\mathbf{- 2 8 4 , 9 7 9}$ \\
\hline Boali & $1,678,226$ & $1,869,159$ & 190,933 \\
\hline Bane & $1,574,575$ & $1,862,748$ & 288,173 \\
\hline Divandareh & $2,135,504$ & $2,106,709$ & $-28,795$ \\
\hline Kamyaran & $1,677,390$ & $1,962,443$ & 285,053 \\
\hline Dehgolan & $2,154,439$ & $2,125,360$ & $\mathbf{- 2 9 , 0 7 9}$ \\
\hline Ghrove & $1,613,228$ & $1,910,120$ & 296,892 \\
\hline Bijar & $2,286,035$ & $3,032,650$ & 746,615 \\
\hline Total & $1,727,650$ & $1,753,085$ & 25,435 \\
\hline
\end{tabular}

building depreciation and dialysis machines, which are usually up to $20 \%$ of costs, are not calculated.

\section{Conclusion}

The cost of dialysis service in dialysis centers of hospitals affiliated to Kurdistan University of Medical Sciences and the tariffs of insurance companies are far apart. Since the service tariff is declared on the basis of specific calculations and percentages, and to determine this amount, the exact costs of that service are not specified, consequently there is a deviation between the tariff and the actual cost. Therefore, hospitals will be in trouble to recoup costs based on tariffs. So there are two ways to increase the hemodialysis service tariffs or manage costs.

\section{Ethical disclosure}

None declared.

\section{Acknowledgements}

Authors would like to thank hospital revenue units and head nurses of dialysis centers all over to help us conducting this study. Also we thank Vice Chancellor for research of Kurdistan University of Medical Sciences to support this study financially.

\section{Author Contributions}

All the authors have accepted responsibility for the entire content of this submitted manuscript and approved submission.

\section{Conflict of interest}

The authors declare that they have no conflict of interest.

\section{Funding/Support}

None declared.

\section{References}

1. Shoghli AR, Hamidi Y. Activity-based costing of health services in Zanjan district health service (19992000).Journal of Zanjan University of Medical Sciences \& Health Services 200; 10(41) : 27-33

2. Antikainen K, Tarja R, Mirva H, Juhani T, Timo K. Activity-based costing process of a daysurgery unitfrom cost accounting to comprehensive management. Journal of Frontiers of E-business Research 2005; 15(6):775-85

3. Karimi I. Health economics book (second volume). Gap publication; 2005.p. 5-32.

4. Hadian M, Mohammadzadeh A, Imani A, Golestani M. Estimation and analysis of health Services costs in Fatemiye Hospital of Semnan University of Medical Sciences in 2007, using step down method. Health management; 2010; 12(37) :39-48

5.Rajabi A. Principles of design and application of activity based costing system in cost price of Hospital Services. Navid Shiraz Publications; 2008.p.18-26

6.Ebadi Fard Azar F F, A Gorji H, Esmaeili R. Calculation and unit cost analysis of health care services delivered in shahriar S.A.bakhshi health center by Activity Based Costing 2006. JHA. 2006; 9 (23) $: 31-40$

7.Ghanbari AM, Haghighi Sh, Memari RA. Verification of cost of dialysis services and tariffs finished state by using activity-based costing in Imam Sajad Hospital, Shahriyar. Journal of Health Administration .2016; 18(62):17-30

8.Rezapoor A, Ebadifard Azar F, Arabloo J. Cost analysis of hemodialysis in Iran: a study from Qazvin (2008-2009). Payesh, Journal of the Iranian Institute For Health Sciences Research 2012؛11(4) : 435-442 